\title{
KESAN DEHIDRASI TAHAP RENDAH TERHADAP PRESTASI KOGNITIF, MOOD DAN SKALA SUBJEKTIF DALAM KALANGAN ATLET BOLA SEPAK LELAKI
}

\author{
Engku Mohd Afzainizam Tengku Abdillah \& Normah Jusoh \\ Fakulti Sains Sukan dan Kejurulatihan, Universiti Pendidikan Sultan Idris, \\ Tanjong Malim, Perak, Malaysia \\ engkumohdafzainizam@gmail.com \\ Jurnal Sains Sukan dan Pendidikan Jasmani 7(2): 12-23, Received: 5 August 2018, \\ Accepted: 30 August 2018
}

\begin{abstract}
Kajian ini bertujuan untuk mengenal pasti kesan dehidrasi tahap rendah terhadap prestasi kognitif, mood dan skala subjektif dalam kalangan atlet bola sepak lelaki Universiti Pendidikan Sultan Idris (UPSI). Empat belas orang atlet yang terlibat dengan min umur adalah $22 \pm 1$ tahun, min berat $65.7 \pm 7.6 \mathrm{~kg}$ dan min tinggi $168 \pm 6 \mathrm{~cm}$ dibahagikan kepada percubaan dehidrasi dan euhidrasi secara rawak. Data asas diambil seminggu sebelum ujikaji sebenar untuk merekodkan masa yang diambil bagi berat badan yang turun tidak melebihi $2 \%$ daripada berat badan asal. Lima belas minit sebelum ujikaji dijalankan, berat, tinggi, kadar nadi dan sampel urin peserta diambil dan seterusnya membuat pemanasan badan dalam tempoh sepuluh minit. Peserta dikehendaki melakukan senaman dehidrasi tahap rendah iaitu berlari perlahan di atas treadmill dalam tempoh 45 minit. Peserta bagi percubaan euhidrasi dibekalkan minuman setiap 15 minit sepanjang ujikaji berlangsung, manakala percubaan dehidrasi tidak dibekalkan minuman. Soal selidik Visual Analogue Scale (VAS) digunakan untuk menilai skala subjektif tahap sakit kepala dan tahap dahaga, manakala prestasi kognitif dinilai melalui Ujian Flanker. Soal selidik Profile of Mood State (POMS) digunakan untuk menilai mood peserta kajian. Urine Specific Gravity sampel urin diukur menggunakan Digital Refractometer untuk menentukan status hidrasi peserta. Data yang diperolehi dari kajian ini telah dianalisis menggunakan Ujian $t$ sampel berpasangan. Terdapat perbezaan signifikan penyusutan berat badan selepas aktiviti bagi percubaan dehidrasi berbanding euhidrasi. Dari segi prestasi kognitif, terdapat perbezaan yang signifikan bagi komponen masa tindak balas tidak kongruen antara percubaan dehidrasi dan euhidrasi. Seterusnya, dapatan kajian menunjukkan tidak terdapat perbezaan yang signifikan bagi keenam-enam dimensi mood antara percubaan dan bagi pembolehubah skala subjektif hanya tahap sakit kepala menunjukkan perbezaan yang signifikan antara percubaan. Secara kesimpulannya, didapati dehidrasi tahap rendah telah memberikan kesan kepada tahap sakit kepala dan masa tindak balas tidak kongruen. Atlet perlu didedahkan dengan strategi pengambilan minuman dan kesedaran tentang status hidrasi bagi mengelakkan dehidrasi, dan seterusnya memastikan kesihatan fizikal dan mental serta prestasi sukan berada dalam keadaan baik.
\end{abstract}

Kata kunci: Dehidrasi, mood, prestasi kognitif, skala subjektif 


\title{
THE EFFECTS OF MILD DEHYDRATION ON COGNITIVE PERFORMANCE, MOOD AND SUBJECTIVE FEELINGS AMONG MALE FOOTBALL PLAYERS
}

\begin{abstract}
This study aims to examine whether mild dehydration affects the cognitive function, mood and subjective feelings among the male football players of Universiti Pendidikan Sultan Idris (UPSI). Fourteen athletes with the mean age of $22 \pm 1$ years, weight of $65.7 \pm 7.6 \mathrm{~kg}$ and height of $168 \pm 6 \mathrm{~cm}$ were randomly divided into dehydration and euhydration trials. The baseline data was collected a week before the main trials to record the time taken by the participants to lose $2 \%$ of the body weight. Fifteen minutes before conducting the trials, the weight, height, pulse rate and urine samples of the participants were collected and then a warm-up session was conducted for ten minutes. The participants were instructed to exercise until mild dehydration by conducting a slow running on a treadmill within forty-five minutes. The participants from the euhydration trial were given drinks every fifteen minutes throughout the experiment, while the dehydration trial were not provided with drinks. A Visual Analogue Scale (VAS) questionnaire was used to determine the subjective feelings of dizziness and thirst, while the cognitive performance was measured by using the Flanker Test. The Profile of Mood State (POMS) questionaire was utilized to measure the mood changes of the participants. Urine Specific Gravity of the urine samples was measured using Digital Refractometer to determine the hydration status of the participants. The data were analysed using the Paired t-test. There was a significant difference in post-exercise body weight loss for the dehydration trial compared to the euhydration trial. In terms of cognitive performance, there was a significant difference for the component of non-congruent reaction time between the dehydration and euhydration trials. Besides, the findings had shown that there were no significant differences for all six dimensions of mood between the trials and there was a significant different for dizziness level between the trials. In conclusion, this study found that mild dehydration has affected the subjective feeling of dizziness and non-congruent reaction time. Thus, the athletes need to be exposed to the fluid intake strategy and the awareness about hydration status in order to avoid dehydration to optimize physical, mental and sports performance.
\end{abstract}

Keywords: Dehydration, mood, cognitive performance, visual analog scale

\section{PENGENALAN}

Status hidrasi, pengambilan air dan kesan dehidrasi telah menjadi topik dalam perdebatan saintifik sejak beberapa tahun kebelakangan ini. Status hidrasi individu pada kebiasaannya diklasifikasikan sebagai euhidrasi iaitu tahap kandungan air dalam badan pada paras normal, manakala dehidrasi pula merujuk kepada kekurangan air dalam badan berbanding paras normal dan hiperhidrasi yang menunjukkan peningkatan sementara jumlah air dalam badan yang melebihi paras normal (Armstrong, 2007; Popkin et al., 2010; Sawka, 1992). Dehidrasi boleh berlaku tanpa sedar semasa melakukan sesuatu aktiviti fizikal (D'Anci et al., 2009) dan merupakan satu keadaan yang boleh memberi kesan buruk kepada kesihatan dan prestasi sukan.

Walaupun keadaan ini jarang sekali berlaku dalam kehidupan seharian, namun keadaan dehidrasi tahap rendah dan sederhana berlaku dengan mudah serta tidak disedari dan perlu diberi perhatian yang serius. Dehidrasi terbahagi kepada tiga tahap iaitu dehidrasi tahap rendah, dehidrasi tahap sederhana dan dehidrasi tahap tinggi. Dehidrasi tahap rendah ditakrifkan sebagai satu keadaan apabila kehilangan air dalam badan sebanyak $1 \%$ hingga $2 \%$ daripada 
berat badan, manakala dehidrasi tahap sederhana berlaku apabila kehilangan air dalam badan sebanyak 2.5 hingga 5\% daripada berat badan (Casa et al., 2000). Perubahan kandungan air dalam badan diukur melalui perubahan berat badan kerana pada dasarnya kehilangan air adalah sama dengan kehilangan berat badan semasa seseorang itu dalam keseimbangan kalori. Kecekapan bagi sistem kardiovaskular dan buah pinggang boleh terganggu disebabkan defisit dalam cecair badan dan kedua-dua sistem ini adalah penting untuk mengekalkan fungsi fisiologi dalam badan manusia seperti suhu badan dan tekanan darah (McArdle, Katch \& Katch, 2014).

Hidrasi yang mencukupi adalah salah satu faktor yang penting untuk mencegah kemalangan atau kecederaan semasa aktiviti fizikal dijalankan dalam keadaan suhu bilik ataupun suhu panas. Hal ini adalah demikian kerana ia mampu meningkatkan prestasi fizikal dan juga mental seseorang (Ritz \& Berrut, 2005; Kenefick \& Sawka, 2007). Popkin, D’Anci dan Rosenberg (2010) berpendapat dehidrasi bukanlah satu keadaan yang wajar dan perlu diberi perhatian tidak kira dehidrasi tahap rendah ataupun lebih tinggi kerana ia bermakna terdapat gangguan dalam fungsi homeostasis tubuh. Secara tidak langsung, perkara ini boleh menjejaskan keupayaan kognitif, mood dan sekali gus memberi kesan kepada prestasi kognitif dan juga prestasi fizikal semasa melakukan aktiviti yang memerlukan penggunaan kemahiran mental.

Ketika menjalani aktiviti fizikal adalah penting dalam mengekalkan fungsi fizikal dan kesihatan fisiologi badan serta pada masa yang sama perlu mengekalkan tahap kesihatan otak dan prestasi kognitif (Kirk-Sanchez \& McGough, 2013). Aktiviti fizikal yang dilakukan secara berterusan dan peningkatan beban kerja boleh menyebabkan dehidrasi secara tidak sedar dan berlaku pengurangan tenaga secara umumnya sekaligus memberi kesan ke atas prestasi mental (Davis \& Bailey, 1997).

Berdasarkan kepada beberapa kajian yang lepas telah mengenal pasti terdapat beberapa domain prestasi kognitif yang mengalami kemerosotan akibat daripada dehidrasi (Sharma, Sridharan, Pichan \& Panwar, 1986). Prestasi kognitif seseorang boleh diklasifikasikan dalam beberapa domain utama iaitu memori, perhatian, persepsi, psikomotor dan juga kemahiran bahasa dan setiap daripada domain kognitif ini boleh dipecahkan kepada beberapa fungsi yang lain. Contohnya, fungsi memori terbahagi kepada memori jangka pendek dan memori jangka panjang. Selain itu, perbezaan boleh dibuat dengan mengambil kira jenis-jenis maklumat yang diterima seperti melalui pendengaran, penglihatan, secara lisan, abstrak dan juga prosedur. Menurut Schmitt, Benton dan Kallus (2005), prestasi kognitif melalui domain perhatian dapat dikelaskan secara pemilihan, pembahagian dan akan dikekalkan manakala fungsi eksekutif pula merangkumi proses yang lebih kompleks yang merangkumi aspek pemikiran, perancangan, pembentukan konsep, penilaian dan pemikiran yang strategik.

Tahap dehidrasi yang melebihi $2 \%$ daripada berat badan boleh menyebabkan kemerosotan dalam aspek tumpuan seseorang dan dapat meningkatkan keletihan, kelesuan dan juga tahap rasa mengantuk serta tahap sakit kepala dalam kalangan peserta kajian (Patel et al., 2007; Cian et al., 2001; D’Anci et al., 2009; Sharma et al., 1986). Selain itu juga, tedapat kajian yang menunjukkan bahawa tahap kelesuan boleh menyebabkan aliran darah perlahan akibat daripada dehidrasi dan hal ini sekali gus menyebabkan sistem kardiovaskular terpaksa bekerja lebih keras bagi menampung jumlah oksigen (Casa et al., 2000; McArdle et al., 2014).

Walaubagaimanapun, terdapat kajian yang mendapati tiada kesan negatif dehidrasi tahap rendah terhadap prestasi fizikal (Ganio et al., 2011). Manakala, Bandelow dan rakanrakan (2010) mendapati tiada kesan yang jelas apabila berlaku dehidrasi tahap rendah terhadap prestasi kognitif dalam kalangan atlet bola sepak. Oleh itu, kajian ini bertujuan untuk mengenal pasti kesan dehidrasi tahap rendah terhadap prestasi kognitif, mood dan skala subjektif dalam kalangan atlet bola sepak lelaki. Kami menjangkakan tidak terdapat perbezaan signifikan kesan 
dehidrasi tahap rendah terhadap prestasi kognitif, mood dan skala subjektif dalam kalangan peserta kajian.

\section{METODOLOGI}

\section{Reka bentuk kajian}

Kajian ini adalah berbentuk randomised cross-over trial yang mana peserta kajian perlu menjalani percubaan sebanyak dua kali iaitu tanpa minuman (DE) dan dengan minuman (EU). Pembolehubah bersandar adalah prestasi kognitif, mood dan skala subjektif, manakala pembolehubah bebas adalah percubaan euhidrasi dan dehidrasi.

\section{Peserta kajian}

Peserta kajian terdiri daripada 14 orang pemain bola sepak lelaki yang mewakili UPSI dalam kejohanan peringkat Majlis Sukan Universiti Malaysia (MASUM). Kesemua peserta adalah sihat tubuh badan, bebas daripada sebarang penyakit kronik, tidak mengalami sebarang kecederaan fizikal dalam tempoh enam bulan lepas dan tidak merokok. Peserta telah diberi penerangan secara lisan dan bertulis tentang eksperimen dan menandatangani borang persetujuan menjadi peserta kajian. Prosedur kajian dijalankan mengikut prosedur standard Declaration of Helsinki.

\section{Instrumen kajian}

Bagi menguji kesan dehidrasi tahap rendah terhadap prestasi kognitif atlet bola sepak ini, Ujian Eriksen Flanker (Eriksen \& Eriksen, 1974) dipilih sebagai instrumen kajian. Manakala untuk menguji mood dan skala subjektif peserta kajian inventori Profile of Mood States (POMS) (McNair, Lorr \& Droppleman, 1971) dan Visual Analogue Scale (VAS) (Bond \& Lader, 1974)) digunakan. Untuk penyediaan soal selidik proses alih bahasa (back to back translation) telah digunakan dan indeks kebolehpercayaan ialah 0.82 bagi Falnker, 0.84 bagi POMS dan 0.81 bagi VAS.

Selain itu, status hidrasi diukur menggunakan refraktometer mudah alih PAL-10S (Atago, Jepun), manakala berat dan tinggi peserta diukur masing-masing menggunakan Omron Karada (Omron, Jepun) dan stadiometer (Harpenden, UK).

Dalam kajian ini, aktiviti fizikal menggunakan senaman selama 45 minit tana minuman diberikan kepada percubaan dehidrasi manakala percubaan euhidrasi telah dibekalkan minuman semasa aktiviti fizikal.

\section{Prosedur kajian}

Seminggu sebelum percubaan dijalankan, peserta telah menjalani ujian data asas untuk merekodkan masa yang diambil bagi berat badan yang turun di antara $1 \%$ dan tidak melebihi $2 \%$ daripada berat badan asal. 


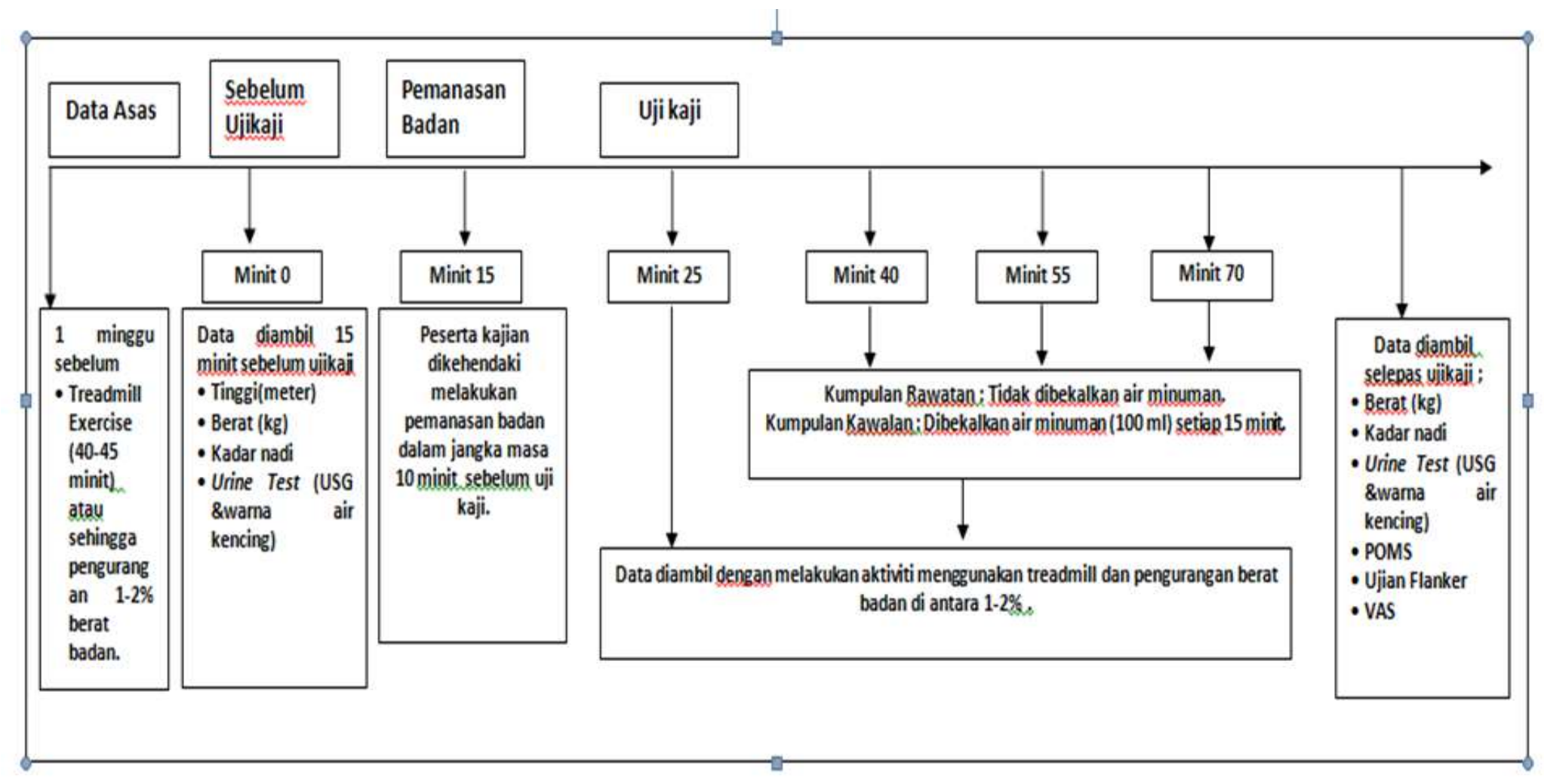

Rajah1: Gambarajah skematik bagi prosedur eksperimen.

Seterusnya, sampel air kencing diambil 15 minit sebelum menjalani ujian untuk merekod status hidrasi. Peserta membuat aktiviti pemanasan badan selama 10 minit sebelum memulakan aktiviti fizikal dengan menggunakan treadmill (Sole TT8, USA). Mereka dikehendaki berlari perlahan di atas treadmill selama $40 \pm 5$ minit dengan kelajuan yang ditetapkan $(5.6 \mathrm{~km} / \mathrm{j}, 5 \% \mathrm{grad})$ dan dalam keadaan suhu bilik $\left(27 \pm 3{ }^{\circ} \mathrm{C}\right)$. Bagi sesi percubaan euhidrasi, mereka dibekalkan air minuman sebanyak $100 \mathrm{~mL}$ setiap 15 minit bagi mengekalkan tahap hidrasi dalam badan. Semasa melakukan aktiviti fizikal, kadar nadi jantung diambil setiap 10 minit dengan menggunakan Heart Rate Monitor, (model CHR100, Casio, Japan). Dalam masa yang sama juga, peserta diberikan Visual Analogue Scale (VAS) untuk memantau tahap dahaga dan sakit kepala sepanjang menjalani aktiviti fizikal. Apabila selesai melakukan aktiviti fizikal ini, peserta sekali lagi memberi sampel air kencing dan membuat timbangan berat badan untuk merekod bacaan sebelum dan selepas menjalani aktiviti senaman dehidrasi tahap rendah.

Setelah selesai melakukan aktiviti senaman, peserta dibenarkan berehat dalam tempoh 10 minit bagi mengeringkan badan dan rambut dengan menggunakan tuala yang telah disediakan. Seterusnya peserta dikehendaki untuk menjalani ujian kognitif iaitu Ujian Eriksen Flanker. Soal selidik POMS diedarkan sejurus peserta selesai melakukan Ujian Eriksen Flanker bagi mengukur tahap mood mereka selepas melakukan aktiviti fizikal dan Visual Analogue Scales (VAS) untuk menentukan skala subjektif iaitu tahap dahaga dan sakit kepala peserta. Peserta mengulangi percubaan ini secara crossover iaitu menjalankan pengujian dalam keadaan dehidrasi atau euhidrasi mengikut giliran. 


\section{Analisis data}

Data dianalisis dengan menggunakan perisian Statistical Package for Science Social (SPSS) versi 20.0. Data demografi peserta dianalisis secara deskriptif menggunakan min dan sisihan piawai. Analisis Ujian t sampel berpasangan digunakan untuk membandingkan skor min bagi percubaan euhidrasi dan dehidrasi terhadap pembolehubah bersandar prestasi kognitif mood dan skala subjektif. Aras signifikan ditetapkan pada $\mathrm{p}<0.05$.

\section{DAPATAN KAJIAN}

\section{Demografi peserta}

Jadual 1 menunjukkan peserta berumur dalam lingkungan $22 \pm 1$ tahun. Manakala min bagi ketinggian peserta adalah dalam lingkungan $168 \pm 6 \mathrm{~cm}$. Bagi berat badan peserta kajian pula secara keseluruhannya adalah dalam lingkungan $65.7 \pm 7.6 \mathrm{~kg}$.

Jadual 1: Taburan demografi peserta $(n=14)$

\begin{tabular}{ll}
\hline Pembolehubah & Min \pm sisihan piawai \\
\hline Umur (tahun) & $22 \pm 1$ \\
Tinggi $(\mathrm{cm})$ & $168 \pm 6$ \\
Berat $(\mathrm{kg})$ & $65.7 \pm 7.6$ \\
\hline
\end{tabular}

\section{Status hidrasi}

Dalam kajian yang dijalankan, dehidrasi tahap rendah dianggar melalui pengurangan berat badan selepas menjalani aktiviti senaman dehidrasi iaitu pengurangan berat badan antara $1 \%$ hingga $2 \%$ daripada berat badan asal. Analisis Ujian -t Sampel Berpasangan digunakan untuk menentukan samada perbezaan yang signifikan selepas melakukan senaman dehidrasi antara dua percubaan DE dan EU.

Jadual 2 menunjukkan nilai min yang diperolehi bagi berat badan peserta semasa percubaan DE sebelum melakukan aktiviti senaman dehidrasi tahap rendah adalah $65.6 \pm 8.0$ $\mathrm{kg}$, manakala min berat badan peserta kajian bagi percubaan EU pula adalah $65.8 \pm 7.6 \mathrm{~kg}$. Berlaku perubahan berat badan dalam kalangan peserta kajian selepas melakukan aktiviti senaman dehidrasi selama 45 minit yang mana peserta semasa DE mengalami penyusutan berat badan sebanyak $1.5 \%$ berbeza dengan percubaan EU yang mengalami penyusutan berat badan dengan hanya $0.2 \%$ sahaja.

Jadual 2: Perbandingan status hidrasi antara percubaan dehidrasi (DE) dan euhidrasi (EU).

\begin{tabular}{|c|c|c|c|c|c|c|}
\hline \multirow[t]{2}{*}{ Pembolehubah } & \multicolumn{3}{|c|}{ EU } & \multicolumn{3}{|c|}{$\mathrm{DE}$} \\
\hline & Sebelum & Selepas & $\begin{array}{c}\text { Nilai } \\
\mathrm{p}\end{array}$ & Sebelum & Selepas & $\begin{array}{c}\text { Nilai } \\
\mathrm{p}\end{array}$ \\
\hline USG & $1.022 \pm 0.006$ & $1.019 \pm 0.008$ & 0.025 & $1.023 \pm 0.004$ & $1.024 \pm 0.004$ & 0.377 \\
\hline $\begin{array}{l}\text { Berat Badan } \\
\quad(\mathrm{kg})\end{array}$ & $65.8 \pm 7.6$ & $65.7 \pm 7.7$ & 0.05 & $65.6 \pm 8.0$ & $64.6 \pm 7.8$ & 0.00 \\
\hline $\begin{array}{c}\text { Peratus } \\
\text { pengurangan }\end{array}$ & & 0.2 & & & 1.5 & \\
\hline
\end{tabular}




\begin{tabular}{|c|c|c|c|c|c|c|}
\hline \multirow[t]{2}{*}{ Pembolehubah } & \multicolumn{3}{|c|}{ EU } & \multicolumn{3}{|c|}{$\mathrm{DE}$} \\
\hline & Sebelum & Selepas & $\begin{array}{c}\text { Nilai } \\
\text { p }\end{array}$ & Sebelum & Selepas & $\begin{array}{c}\text { Nilai } \\
\mathrm{p}\end{array}$ \\
\hline
\end{tabular}

berat badan

$(\%)$

Status hidrasi berdasarkan nilai min USG sebelum aktviti senaman dehidrasi tahap rendah bagi percubaan EU adalah 1.022 \pm 0.006 . Manakala bagi percubaan DE nilai min bagi USG adalah 1.023 \pm 0.004 . Selepas melakukan aktiviti senaman dehidrasi didapati berlaku perubahan pada status hidrasi peserta kajian bagi kedua-dua kumpulan. Berlaku peningkatan nilai USG bagi percubaan DE iaitu $1.024 \pm 0.004$, dan berbeza dengan percubaan EU yang mengalami penyusutan nilai USG dengan nilai min $1.019 \pm 0.008$.

\section{Kesan dehidrasi tahap rendah terhadap prestasi kognitif, mood dan skala subjektif}

Jadual 3 menunjukkan dapatan bagi prestasi kognitif, mood dan skala subjektif antara percubaan EU dan DE. Berdasarkan kepada hasil analisis Ujian Eriksen, didapati nilai min untuk keseluruhan jawapan betul bagi DE adalah lebih rendah iaitu 95.7 $\pm 5.5 \%$, manakala bagi EU didapati nilai min adalah $98.9 \pm 2.1 \%$. Analisis Ujian-t Sampel Berpasangan bagi jawapan betul keseluruhan Ujian Eriksen Flanker kedua-dua percubaan adalah tidak mempunyai perbezaan yang signifikan $(\mathrm{p}=0.057)$.

Jadual 3: Prestasi kognitif, mood dan skala subjektif selepas melakukan aktiviti senaman dehidrasi tahap rendah antara dehidrasi (DE) dan euhidrasi (EU).

\begin{tabular}{llll}
\hline Pemboleh Ubah & EU & DE & Nilai p \\
\hline $\begin{array}{l}\text { Ujian Eriksen Flanker } \\
\text { Jawapan betul (\%) }\end{array}$ & $98.9 \pm 2.1$ & $95.7 \pm 5.5$ & 0.057 \\
$\begin{array}{l}\text { Masa Tindak Balas Kongruen } \\
\text { (saat) }\end{array}$ & $509.13 \pm 121.19$ & $576.63 \pm 147.46$ & 0.251 \\
$\begin{array}{l}\text { Masa Tindak Balas } \\
\text { Kongruen (saat) }\end{array}$ & $536.53 \pm 116.46$ & $807.38 \pm 409.42$ & $0.014^{*}$ \\
$\begin{array}{l}\text { POMS } \\
\text { Ketegangan }\end{array}$ & & & \\
Bertenaga & $12.2 \pm 3.2$ & $14.3 \pm 4.7$ & 0.140 \\
Keletihan & $20.3 \pm 3.3$ & $22.2 \pm 3.7$ & 0.163 \\
Kekeliruan & $19.5 \pm 3.5$ & $18.7 \pm 3.2$ & 0.575 \\
Kemarahan & $19.5 \pm 3.2$ & $18.9 \pm 2.8$ & 0.618 \\
Kemurungan & $20.1 \pm 3.1$ & $20.8 \pm 3.4$ & 0.645 \\
VAS & $14.0 \pm 3.9$ & $14.9 \pm 3.3$ & 0.548 \\
Tahap Sakit Kepala (mm) & $10.21 \pm 8.35$ & $21.50 \pm 17.49$ & $0.045^{*}$ \\
Tahap Dahaga (mm) & $21.50 \pm 18.94$ & $39.50 \pm 20.36$ & 0.052 \\
*Aras signifikan ditetapkan $\mathrm{p}<0.05$ & & &
\end{tabular}

Bagi masa tindak balas kongruen menunjukkan bahawa nilai min bagi DE lebih tinggi iaitu 576.63 \pm 147.46 saat berbanding EU iaitu 509.13 \pm 121.19 saat. Ujian-t Sampel Berpasangan menunjukkan tidak terdapat perbezaan yang signifikan antara kedua-dua percubaan $(\mathrm{p}=0.251)$. Bagi masa tindak balas tidak kongruen Ujian Eriksen Flanker pula, hasil 
analisis mendapati nilai min bagi EU lebih rendah iaitu 536.53 \pm 116.46 saat berbanding DE dengan nilai $807.38 \pm 409.41$ saat. Ujian-t Sampel Berpasangan masa tindak balas tidak kongruen Ujian Eriksen Flanker bagi kedua-dua percubaan mempunyai perbezaan yang signifikan $(\mathrm{p}=0.014)$.

Dapatan bagi POMS mendapati dimensi ketegangan bagi mood peserta tidak mempunyai perbezaan yang signifikan $(\mathrm{p}=0.140)$ antara kedua-dua percubaan. Nilai min bagi EU (12.2 \pm 3.2$)$ lebih rendah berbanding DE (14.3 \pm 4.7$)$. Bagi dimensi bertenaga pula mendapati nilai min bagi EU (20.3 \pm 3.3$)$ lebih rendah dan tidak signifikan berbanding DE (22.2 \pm 3.7$)$. Bagi dimensi yang ketiga POMS iaitu dimensi keletihan, dapatan menunjukkan tidak terdapat perbezaan yang signifikan ( $\mathrm{p}=0.575)$ bagi EU $(19.5 \pm 3.5)$ dan bagi $\mathrm{DE}(18.8 \pm 3.2)$. Bagi dimensi kekeliruan nilai min bagi EU (19.5 \pm 3.2$)$ lebih tinggi berbanding DE (18.9 \pm 2.8$)$ tetapi tidak signifikan $(\mathrm{p}=0.618)$. Begitu juga dimensi kemarahan tidak menunjukkani perbezaan yang signifikan $(\mathrm{p}=0.645$ antara EU (20.1 \pm 3.1$)$ dan DE (20.8 \pm 3.5$)$. Manakala bagi dimensi kemurungan menunjukka nilai min bagi EU (14.0 3.9 lebih tinggi tetapi tidak signifikan berbanding DE (14.9 \pm 3.3$)$.

Merujuk kepada hasil analisis VAS bagi keadaan sakit kepala selepas melakukan senaman dehidrasi tahap rendah dalam tempoh 45 minit, mendapati nilai min bagi EU $(10.21 \pm 8.35 \mathrm{~mm})$ lebih rendah dan signifikan berbanding DE $(21.50 \pm 17.49 \mathrm{~mm})$. Manakala bagi tahap dahaga peserta kajian selepas melakukan senaman dehidrasi tahap rendah, dapatan menunjukkan nilai min bagi DE $(39.50 \pm 20.36 \mathrm{~mm})$. Berbanding EU $(21.50 \pm 18.936 \mathrm{~mm})$. Ujian-t Sampel Berpasangan bagi tahap dahaga kedua-dua kumpulan kajian tidak terdapat perbezaan yang signifikan $(\mathrm{p}=0.052)$.

\section{PERBINCANGAN}

\section{Status hidrasi}

Hasil analisis data yang telah dibuat terhadap status hidrasi sebelum dan selepas peserta kajian menjalani aktiviti senaman dehidrasi tahap rendah selama 45 minit bagi kedua-dua keadaan euhidrasi (EU) dan dehidrasi (DE) menunjukkan berlaku penyusutan berat badan selepas melakukan aktiviti tersebut. Percubaan DE menunjukkan berlaku penyusutan sebanyak $1.5 \%$ daripada berat badan asal sebelum menjalani aktiviti senaman dehidrasi tahap rendah. Manakala bagi percubaan EU, penyusutan berat badan juga berlaku tetapi dengan nilai yang lebih kecil iaitu kira-kira $0.2 \%$ daripada berat badan asal. Oleh itu, peserta dalam percubaan DE telah mengalami dehidrasi tahap rendah apabila berlakunya penyusutan cecair daripada berat badan asal sebanyak $1.5 \%$ iaitu dalam lingkungan 1 hingga $2 \%$ sebagaimana yang telah dinyatakan oleh penyelidik terdahulu iaitu Szinnai et al. (2005). Dapatan kajian ini disokong dengan hasil kajian Ganio et al. (2011) yang mendapati kesan dehidrasi berlaku semasa latihan dengan min penyusutan berat badan adalah $1.5 \%$ berbanding dengan kumpulan euhidrasi yang masih dalam keadaan hidrasi normal apabila penyusutan mengalami penyusutan kurang daripada 1\%. Dapatan kami juga disokong oleh Armstrong et al. (2011) yang mendapati peseta kumpulan peserta kumpulan euhidrasi hanya mengalami pengurangan berat badan sebanyak $0.12 \%$.

Selain itu juga, status hidrasi diukur melalui nilai USG sebelum dan selepas aktiviti senaman dehidrasi tahap rendah. Dapatan kajian menunjukkan sebelum melakukan aktiviti senaman dehidrasi selama 45 minit, peserta bagi kedua-dua percubaan dalam keadaan hipohidrasi dengan nilai min USG > 1.020 (Casa et al., 2000). Selepas selesai aktiviti senaman dehidrasi tahap rendah didapati berlaku perubahan bagi kedua-dua percubaan yang mana 
percubaan DE mengalami peningkatan nilai USG iaitu 1.024 \pm 0.004 dan kekal dalam keadaan hipohidrasi. Berbeza dengan percubaan EU yang mengalami penurunan nilai USG iaitu $1.019 \pm 0.008$ dan dikategorikan dalam keadaan hidrasi normal. Oleh itu, dapat disimpulkan bahawa peserta memang berada dalam keadaan dehidrasi tahap rendah semasa sesi percubaan DE.

\section{Kesan dehidrasi tahap rendah terhadap prestasi kognitif, mood dan skala subjektif}

Hasil dapatan Ujian Eriksen Flanker menunjukkan bahawa peserta semasa percubaan EU yang telah dibekalkan dengan pengambilan minuman sepanjang aktiviti berlangsung telah memperlihatkan keputusan yang lebih baik berbanding semasa percubaan DE yang tidak diberikan sebarang minuman. Walaupun tiada perbezaan yang signifikan kesan dehidrasi tahap rendah terhadap prestasi kognitif, namun perbezaan dari segi peratus keseluruhan jawapan betul, masa tindak balas kongruen dan masa tindak balas tidak kongruen menunjukkan peserta semasa percubaan EU adalah lebih baik berbanding semasa dalam keadaan dehidrasi. Hasil dapatan kami adalah selari dengan kajian Tomporowski et al. (2007) dan Ganio et al. (2011) yang mengkaji kesan dehidrasi tahap rendah terhadap prestasi kognitif dan mood yang membuktikan bahawa dehidrasi boleh menyebabkan berlakunya penurunan prestasi kognitif. Secara umum peserta dalam keadaan dehidrasi memerlukan masa yang lebih lama bagi tindakbalas kongruen dan tidak kongruen. Adan (2012) menyatakan bahawa pengambilan makanan dan minuman semasa melakukan aktiviti fizikal boleh mempengaruhi prestasi fizikal dan kognitif serta ianya memainkan peranan yang penting. Hasil kajian Masento et al. (2014) berkaitan kesan status hidrasi terhadap prestasi kognitif dan mood membuktikan bahawa penggunaan air semasa melakukan aktiviti telah mempengaruhi prestasi kognitif dan mood. Oleh itu, penekanan terhadap pengambilan minuman atau cecair bagi mengembalikan rehidrasi dalam badan perlu diambil berat sebagai nutrien penting yang dapat memberi manfaat kepada prestasi fizikal dan kognitif seseorang.

Walaubagaimanapun, kajian oleh Armstrong et al. (2011) yang bertujuan untuk mengkaji kesan dehidrasi tahap rendah terhadap prestasi kognitif dalam kalangan peserta wanita mendapati kebanyakan aspek masa tindak balas tidak terjejas teruk kesan daripada dehidrasi. Penemuan ini juga disokong oleh oleh Szinnai et al. (2005) yang mendapati tidak ada perubahan yang jelas prestasi kognitif dalam kalangan peserta lelaki dan wanita apabila badan dalam keadaan dehidrasi $<2 \%$ kehilangan berat badan. Oleh kerana bukti yang ada tidak konklusif, maka kajian lanjut tentang aspek perbezaan jantina boleh dilakukan pada masa akan datang.

Aspek kedua yang dikaji adalah tentang kesan dehidrasi tahap rendah terhadap mood antara dua keadaan iaitu semasa dehidrasi dan euhidrasi. Terdapat enam dimensi mood yang diukur dengan menggunakan instrumen POMS iaitu ketegangan, bertenaga, keletihan, kekeliruan, kemarahan dan kemurungan. Kesemua dimensi ini menunjukkan tidak ada perbezaan signifikan bagi kedua-dua percubaan DE dan EU dengan nilai $\mathrm{p}>0.05$.

Walaubagaimanapun, percubaan DE mencatatkan nilai yang lebih tinggi bagi dimensi ketegangan, bertenaga, kemarahan dan kemurungan. Hanya dua dimensi iaitu kekeliruan dan keletihan yang menunjukkan bahawa percubaan EU adalah lebih tinggi berbanding DE. Apabila mengalami dehidrasi, secara tidak langsung akan mempengaruhi tingkah laku dan mood. D'Anci et al. (2009) dan Edmond et al. (2013) menyatakan bahawa dehidrasi akan menyebabkan berlaku peningkatan bagi dimensi mood iaitu keletihan, kemarahan, ketegangan, kekeliruan dan kemurungan. Perkara ini telah terbukti sebagaimana dapatan kajian yang menunjukkan peningkatan dalam dimensi ketegangan, kemarahan dan juga kemurungan dikalangan peserta kajian semasa percubaan DE. 
Selain itu, dapatan kajian kami menunjukkan terdapat perbezaan antara untuk skala subjektif bagi tahap rasa dahaga dan keadaan sakit kepala antara percubaan DE dan EU. Hasil dapatan kajian ini adalah hampir sama dengan kajian yang telah dilakukan oleh Shirreffs et al. (2004) yang mengkaji berkaitan dengan kesan sekatan pengambilan cecair terhadap status hidrasi dan skala subjektif dalam kalangan peserta lelaki dan wanita. Daripada hasil dapatan kajian mereka mendapati tiada perbezaan signifikan tahap rasa dahaga dalam kalangan peserta, manakala tahap sakit kepala pula jelas menunjukkan terdapat perbezaan yang signifikan ( $\mathrm{p}$ <0.05). Berdasarkan kepada kajian mereka juga, jelas mendapati peserta kajian yang mengalami peningkatan tahap sakit kepala dan keupayaan mereka dalam menumpukan perhatian dan kecerdasan telah berkurangan apabila mereka telah disekat daripada mengambil sebarang minuman atau cecair. Perubahan yang berlaku dalam status hidrasi boleh menyebabkan berlaku kemerosotan atau peningkatan terhadap tahap sakit kepala peserta (Armstrong et al., 2011). Ganio et al. (2011) dalam kajian mereka juga mendapati kesan daripada dehidrasi tahap rendah (1.59\% kehilangan berat badan) terhadap skala subjektif rasa sakit kepala adalah lebih tinggi berbanding kumpulan euhidrasi.

\section{KESIMPULAN}

Secara keseluruhannya, kajian mengenai dehidrasi tahap rendah terhadap prestasi kognitif, mood dan skala subjektif dalam kalangan atlet bola sepak lelaki MASUM UPSI menunjukkan tidak terdapat perbezaan yang signifikan antara percubaan dehidrasi dan euhidrasi bagi kebanyakan pemboleubah yang diukur. Walau bagaimanapun, terdapat perbezaan dari segi min dan sisishan piawai menunjukkan percubaan dehidrasi mencatatkan nilai yang tinggi bagi prestasi kognitif, mood dan juga skala subjektif berbanding kumpulan euhidrasi.

Oleh itu penekanan terhadap status hidrasi perlu dititikberatkan dalam kalangan atlet bola sepak khususnya dan atlet sukan lain juga. Jurulatih dan pihak pengurusan sukan seharusnya mengambil berat tentang status hidrasi atlet dan perlu mendedahkan atlet dengan amalan pemakanan yang betul bagi memastikan prestasi fizikal, emosi dan kognitif pada tahap yang optimum.

\section{RUJUKAN}

Adan, A. (2012). Cognitive performance and dehydration. Journal of American College of Nutrition, 31(2), 71-78.

Armstrong, L. E. (2007). Assessing hydration status: the elusive gold standard attention in male basketball players. Journal of Medicine and Science in Sports and Exercise, 39, 976-983.

Armstrong, L. E., Ganio, M. S., Casa, D. J., Lee, E. C., McDermott, B. P., Klau, J. F., Jimenez, L. Bellego, L. L., Chevillotte, E., \& Lieberman, H. R. (2011). Mild dehydration affects mood in healthy young women. Journal of Nutrition, 142(2), 382-388.

Bandelow, S., The effects of exercise, heat, cooling and rehydration strategies on cognitive function in football players. Scandinavian Journal of Medicine and Science in Sport, 20(3), 148-160.

Bond, A., \& Lader, M. (1974). The use of analogue scale in rating subjective feelings. British Journal of Medical Psychology,47, 211-218.

Casa, D. J., Armstrong, L. E., Hilman, S. K., Montain, S. J., Reiff, R. V., Rich, B. S., Roberts, W. O., \& Stonee, J. A. (2000). National athletic trainers association position statement: Fluid replacement for athletes. Journal of Athletic Training, 35, 212-224. 
Cian, C., Barraud, P. A., Melin, B., \& Raphel, C. (2001). Effects of fluid ingestion on cognitive function after heat stress or exercise-induced dehydration. International Journal of Psychophysiology, 42, 243-251.

D’Anci, K. E., Vibhakar, A., Kanter, J. H., Mahoney, C. R., \& Taylor, H. A. (2009). Voluntary dehydration and cognitive performance in trained college athletes. Perceptual and Motor Skills, 109, 251-269.

Davis, J. M., \& Bailey, S. P. (1997). Possible mechanisms of central nervous system fatigue during exercise. Medicine and Science in Sports and Exercise, 29, 45-57.

Edmonds, C. J., Crombie, R. \& Gardner, M. R. (2013). Subjective Thirst Moderates Changes in Speed of Responding Associated with Water Consumption. Frontiers in Human Neuroscience, 7, 1-8.

Eriksen, B. A., \& Eriksen, C. W. (1974). Effects of noise letters upon the identification of a target letter in a nonsearch tast. Perception and Psychophysics. 16(1), 143-149.

Ganio, M. S., Armstrong, L. E., Casa, D. J., Lee, E. C., McDermott, B. P., Klau, J. F., Jimenez, L., Le Bellego, L., Chevillotte, E., \& Lieberman, H. R. (2011). Mild dehydration impairs cognitive performance and mood of men. British Journal Of Nutrition, 106, 1535-1543.

Kenefick, R. W., \& Sawka, M. N. (2007). Hydration in the work site. Journal of The American College of Nutrition, 26, 597-603.

Kirk-Sanchez, N. J., \& McGough, E. L. (2013). Physical exercise and cognitive performance in the elderly: Current perspectives. Review: Clinical Interventions in Aging, 9, 51-62.

Masento, N. A., Golightly, M., Field, D. T., Butler, L. T., \& Reekum, C. M. (2014). Effects of hydration status on cognitive performance and mood. British Journal of Nutriton, 111(10), 1841-1852.

McArdle, W. D., Katch, F. L., \& Katch, V. L. (8th Ed.). (2014). Exercise Physiology: Energy, Nutrition and Human Performance. New York, NY: Lippincott Williams \& Wilkins.

McNair, D. M., Lorr, M. \& Droppelma, L. F. (1971). Manual for The Profile of Mood States. San Diego, CA: Educational and Industrial Testing Service.

Patel, A. V., Mihalik, J. P., Notebaert, A. J., Guskiewicz, K. M., Prentice, W. E. (2007). Neuropsychological performance, postural stability, and symptoms after dehydration. Journal of Athletic Training, 42, 66-75.

Popkin, B. M., D'Anci, K. E., \& Rosenberg, I. H. (2010). Water, hydration and health. Nutrition Reviews, 68, 439-458.

Ritz, P., \& Berrut, G. (2005). The importance of good hydration for day-to-day health. Nutrition Reviews, 63, S6-S13.

Sawka, M. N. (1992). Physiological consequences of hypohydration: exercise performance and thermoregulation. Medicine and Science in Sports and Exercise, 24, 657-670.

Schmitt, J. A., Benton, D., \& Kallus, K. W. (2005). General methodological considerations for the assessment of nutritional influences on human cognitive functions. European Journal of Nutrition, 44(8), 459-464.

Sharma, V. M., Sridharan, K. Pichan, G. \& Panwar, M. R. (1986). Influence of heat-stress induced dehydration on mental functions. Ergonomics Research Society, 29, 791-799.

Shirreffs, S. M., Merson, S. J., Fraser, S. M., Archer, D. T. (2004). The effects of fluid restriction on hydration status and subjective feelings in man. British Journal of Nutrition, 91, 951-958.

Szinnai, G., Schachinger, H., Arnoud, M. J., Linder, L. \& Keller, U. (2005). Effect of water deprivation on cognitive-motor performance in healthy wen and women. American Journal of Physiology. Regulatory, integrative and comparative physiology. 289, 275-280.

Tomporowski, P. D., Beasman, K., Ganio, M. S., Curaton, K. (2007). Effects of dehydration and fluid ingestion on cognition. International Journal Sport Medicine, 28 : 29-36.

ఏ Engku Mohd Afzainizam Tengku Abdillah

Fakulti Sains Sukan dan Kejurulatihan,

Universiti Pendidikan Sultan Idris,

Tg Malim, Perak,

Malaysia

Email: engkumohdafzainizam@gmail.com 